FACTA UNIVERSITATIS

Series: Law and Politics Vol. 18, No 3, 2020, pp. 185-196

https://doi.org/10.22190/FULP2003185D

Review Paper

\title{
COMPARATIVE LAW REVIEW OF LONG-TERM CARE SYSTEMS IN SOME EUROPEAN COUNTRIES *
}

\author{
UDC 364.4(4-672EU) \\ 340.5
}

Marija Dragićević

Faculty of Philosophy, University of Niš, Serbia

\begin{abstract}
The organisation and funding of a long-term care system have been one of the most commonly debated issues in the social policies of developed European countries since the 1920s. The key issue in the debate on the long-term care system is to what extent the population should finance their own needs for custodial care and assistance, and to what extent it should be done by the state. Another important issue is whether the funds for long-term care should only be beneficial for those who cannot pay from their own assets (residual model), or whether long-term care services should be a universal right. The existence of such huge national differences has contributed to the intensity of this debate, both regarding how the system is organised (according to the type of benefits) and how the resources are generated. Bearing in mind the foregoing, in this paper, the author analyses the long-term care systems for people dependant on custodial care and assistance in several most developed European countries. The paper examines their organisation and funding, and highlights their major advantages and disadvantages, which may eventually serve as an indication for improving the domestic system.
\end{abstract}

Key words: long-term care, system, organisation, financing

\section{INTRODUCTION}

Many people cannot take care of themselves due to their old age, illness, disability and similar reasons; thus, they are in need of daily assistance (Jašarević, 2013: 275). Family members often cannot provide specialized services for vulnerable individuals, and they need organised assistance by the community. Considering that the income of these vulnerable groups is often low and their need for social care and assistance by another person entails

Received November $12^{\text {th }} 2020 /$ Accepted November $26^{\text {th }} 2020$

Corresponding author: Marija Dragićević, LL.M., Teaching Assistant, Faculty of Law, University in Niš, Trg Kralja Aleksandra 11, 18000 Niš, Serbia. E-mail: marijad@prafak.ni.ac.rs

${ }^{*}$ This paper is a result of the research within the project Harmonisation of Serbian Legislation with European Union Law, financially supported by the Faculty of Law, University of Niš. 
additional expenses, they have to be financially supported by the state. For these reasons, many countries developed long-term care systems.

Long-term care implies an entire array of services provided to persons with decreased functional abilities of mental or physical nature, who depend on custodial care in performing their basic daily activities. A long-term care system is comprised of medical care, prevention services, rehabilitation, palliative care, assistance at home or in performing instrumental daily activities. The aim of long-term care is to ensure that individuals who cannot completely take care of themselves may maintain the best possible life quality, still keeping the highest possible degree of independence, autonomy, personal fulfilment and human dignity.

The current legal framework for long-term care in Europe is the Revised European Social Charter (1996) ${ }^{1}$, a binding document of the Council of Europe. Article 23 of this Carter regulates the right of elderly people to social protection. Under this Article, the $\mathrm{CoE}$ member states are obliged to ensure the effective exercise of this right: to enable elderly people to freely choose their lifestyle and to lead independent life in their own family environment, and to provide resources, suitable housing, healthcare, adequate support and services that they need for decent life in their states (Article 23 ESC). The European Union countries implement this policy by applying the Open Method of Coordination (OMC). ${ }^{2}$ It is a soft governance method, encompassing pre-arranged goals, standards, guidelines, indicators, and follow-up arrangements; thus, the EU member states choose how to meet the envisaged EU policy goals (Satarić, Milićević Kalašić, 2014: 7). For this reason, provision of long-term care in Europe is characterised by significant differences between (and within) countries, particularly in terms of how the system is organised (public, non-profitable or profitable service providers), the type/kind of provision (cash or in kind allowances), and how the resources are generated (through general taxation, compulsory social security, or voluntary private insurance) (Bettio, Verashchagina, 2012: 4-19).

In addition to different situations in EU states, there are other factors that make the coordination of long-term care policies challenging: the system complexity (mixture of healthcare and social protection, which is additionally complicated by a lack of coordination between them) and the difficulty in monitoring the system (due to the informal nature of the majority of services and the absence of agreed indicators, outcomes and (reasonably) comparative data. Bearing in mind the aforesaid, the primary goal of this paper is to analyse the major trends and challenges in national long-term care policies, and to examine how long-term care systems are organized, funded and managed in several developed European countries. In order to achieve this goal, the author first describes the phenomenon of longterm care and outlines its basic characteristics. In the second part of the paper, the author discusses the encountered challenges and the possible ways of classifying different types of long-term care.. In the third (central) part of the paper, the author provides a comparative law review of long-term care systems in several European countries. In the concluding remarks, the author discusses the major trends and obstacles (or at least some of their elements) which have been encountered by the national long-term care systems, and which stand in the way of a greater interstate standardisation.

\footnotetext{
${ }^{1}$ CoE Revised European Social Charter (CETS No. 163/1996).

${ }^{2}$ See: European Parliament (2014): The Open Method of Coordination (OMC), retrieved 25 October 2020 from https://www.europarl.europa.eu/EPRS/EPRS-AaG-542142-Open-Method-of-Coordination-FINAL.pdf
} 


\section{THE CONCEPT AND BASIC CHARACTERISTICS OF LONG-TERM CARE SYSTEM}

Within the EU community, there is a number of different definitions of long-term care. The broadest definition is provided by the Organisation for Economic Cooperation and Development (OECD), which defined long-term care as: "a cross-cutting policy issue that brings together a range of services for persons who are dependent on help with basic activities of daily living over an extended period of time" (OECD, 2005: 10). Long-term care includes healthcare and social protection services provided at home or in an institutional environment to individuals who need support in performing daily living activities over an extended period of time. Such support includes: assistance in performing basic daily living activities (BDLAs), such as: moving around, eating, dressing, using the bathroom; assistance in performing instrumental daily living activities (IDLAs), such as preparing food, shopping, transportation, etc., as well as nurses' assistance and palliative care (wound dressing, decubitus prevention and treatment, administering medicines, alleviating pain, following-up health status) (Colombo, Llena-Nozal, Mercier, Tjadens, 2011: 39; Lipszyc, Sail, Xavie, 2012: 7-8). Long-term care is provided to elderly people and special vulnerable groups of people, to persons having physical or mental difficulties, who need support and assistance in their basic daily activities. Long-term care mainly covers the needs of the oldest age groups $(80+)$ who are, at the same time, most at risk of long-standing chronic conditions causing physical or mental disabilities and dependency (Muir, 2017: 14).

The definitions of long-term care differ in the EU countries depending on a number of factors: the length of use, the beneficiary's profile, and the scope and types of services. The demarcation line between healthcare and social protection components in long-term care is also quite different. The same thing may be said about the ratio between the use of rehabilitation services and the time spent in treatment in hospitals or other institutions (Republic Institute for Social Welfare Protection, 2008: 2). There are also differences in the long-term care concepts, the perception of "dependency" of a person who is a beneficiary of such services, and whether such support is provided as a financial benefit or a concrete service. Also, there is no concordance between the states in terms of defining the beneficiaries of such services (e.g. an individual or a family), designating the service providers for the entire population of potential beneficiaries, or specifying the roles of the public and the private sector, and the role of the family.

\section{ClassificATION OF LONG-TERM CARE MODELS}

Similarly to the classification of different models of the welfare state and its individual parts (such as pension and invalidity system, healthcare system, etc.), we may pose the question of classification of long-term care models. As with any classification, there is an issue of a great diversity of systems and a great number of variables which the classification is based on. In this case, the diversity is even more prominent.

The basic elements of long-term care system are the philosophy underlying the system, particularly in terms of who bears the responsibility (family or state); how the state organises care (services, cash benefits, combination); the system funding (social security or budget), and the degree of generosity of the state support. As it is fairly complicated to consider all these elements simultaneously, many authors resort to the classification based on only one or two criteria. For instance, Anttonen and Sipilä (1996) classified the s' social 
welfare systems of western European countries based on how the services and their scope are organised. Thus, the identify several models: the "Scandinavian model", based on comprehensive services organised by the state; the "traditional model", based on family care with a limited offer of services; the "British model", where the state is responsible for the provision of services, on a small scale ("residually"); and the "central European subsidiary model", which combines family responsibility with the state support (Anttonen, Sipila, 1996: 87-100). Similarly, based on the question who bears the responsibility for long-term care, Schulz (2010) believes that the European models of social welfare can be generally classified into three categories: the state responsibility models, where responsibility is borne by the state; the family care models, where the family is responsible; and the subsidiary models where the family is supported by the state (Schulz, 2010: 1). Nies et al. (2013) proposed a typology where the complexity of long-term care systems is reduced to four types: standard (mixed), universal (Nordic), family-based, and transitional. This typology starts from three key dimensions for the classification of European long-term care regimes: demand for care (e.g. population in need or at risk of long-term care, and the role of poverty-driven factors); provision of informal care (e.g. the share of individuals providing care to their relatives and multi-generation households), and provision of formal care services (e.g. public expenditure on long-term care, the share of older people receiving formal care services at home or in institutions) (Ilinca, Leichsenring, Rodrigues, 2015: 2). Colombo et al. (2011) consider that, even though long-term care systems are organised in very complex ways (in terms of various combinations of cash benefits), clusters of countries having a similar approach are discernible. Bearing in mind two criteria - the scope of rights (universal v. targeted) and whether the system is set as a unique programme or a combination of measures, they classify the long-term care systems of the OECD countries into three clusters: a) universal systems with a unique programme; b) mixed systems, which can be a combination of several universal programmes or a mix of universal and targeted benefits; and c) targeted systems. Within this division, they further distinguish sub-groups on the basis of additional characteristics, e.g. how the system is financed (contributions or taxes), whether the programme is part of healthcare insurance, etc. (Colombo et al, 2011: 215).

\section{Comparative LaW REVIEW OF SOME European COUNTRIES' LONG-TERM CARE SYSTEMS}

This part of this paper provides an overview of long-term care systems in several European countries, where the systems have reached the highest level of development.

The Netherlands. By enacting the Exceptional Medical Expenses Act (AWBZ), the Netherlands was the first country that introduced a universal compulsory social and healthcare insurance for covering a broad spectre of long-term care services. While public insurance for long-term care was introduced in the Netherlands in 1968, other countries only did it not so long ago, e.g. Germany in 1995, and Japan in 2005 (Schut, Van den Berg, 2012: 103). The basic philosophy of the Dutch model is that the state is responsible for providing long-term care services. The long-term care insurance system is part of healthcare insurance; more specifically, it is envisaged within the framework of compulsory insurance in case of "irregular" medical expenditures. Besides the long-term care, this insurance also covers costs linked to all types of chronic diseases, i.e. all higher costs that would not be covered by private insurance (Mot, Aouragh, De Groot, Mannaerts, 2010: 6). Before a 
person is allowed to use long-term care services in compliance with the AWBZ, it is first necessary to establish if this care is really needed, and if it is, what type of care is needed and how long it should be provided. At first, health professionals were responsible for assessing who will be provided assistance under the AWBZ; in 1997, the task was assigned to regional organisations for the assessment of needs; since 2005, the assessment has been carried out by an independent national institution - the Centre for Needs Assessment (Schut, Van den Berg, 2012: 106). The idea was to make the needs assessment for custodial care and assistance more objective, uniform and independent of personal interests of healthcare service providers (Mot et al, 2010: 7). The key assessment criterion in the longterm care system is health, i.e. the functions that a potential beneficiary cannot perform (as in Germany), and it does not depend on their income and property (as the Medicaid programme in the USA). There are no general classifications of disability level, yet the needed support assessments are carried out on the basis of clear instructions for each beneficiary individually. As far as long-term care services are concerned, the AWBZ covers personal and healthcare, daily care, personal assistants and institutional care, including institutions for accommodation of persons with disabilities, as well as mental health institutions. Cash allowance is paid in a form of "personal budget", the value of which is $25 \%$ lower than the service value. If the beneficiary opts for cash allowance, he/she must present how it was spent (e.g. he/she must prove that he/she used it to buy such services); when buying, he/she is free in selecting the service provider (Mot et al, 2010: 10).

The AWBZ is funded from contributions, participations, and taxes in the event of deficit. The contribution rate amounts to $12.25 \%$ of total income (Donders, Maarse, 2011: 24). Participation differs for institutional and non-institutional beneficiaries. When determining the size of participation for home-based assistance, the assessment takes into account the beneficiary's income, his/her age, and the composition of household where he/lives. The total public expenditures for long-term care in 2015 amounted to $2.62 \%$ of the GBP, which is significantly above the average for the OECD countries; in fact, it is the highest expenditure for long-term care after Sweden (GBP 2.90\%) (Spasova, Baeten, Coster, Ghailani, Peña-Casas, Vanhercke, 2018: 34).

The future of the long-term care system has been the subject matter of intensive debate. The focus is primarily on the feasibility of the system and the reduction of costs. To this effect, individual responsibility for elderly people is promoted; informal family care is minimally used although there is a considerable flexibility in terms of working hours (Mot et al, 2010: 11). Cash benefits (the so-called personal budgets) are another important topic. The number of beneficiaries of personal budgets has significantly increased (from 13,000 in 1998 to 148,000 in 2008) due to "informal care monetarization" (Donders, Maarse, 2011: 24). This led the government to drastically restrict access to cash benefits from 2012 onwards only to people eligible for institutional care (about $10 \%$ of the current 130,000 cash benefits recipients), which should save 0.6-0.7 billion EUR by 2015 (Shut, Sorbe, Høj, 2013: 28). The root of the problem was not cash benefits themselves but rather insufficient screening and monitoring. Thus, it would be preferable to keep a cash benefits scheme for home care but to improve screening and monitoring to avoid unintended use. One way of reducing the need for monitoring could be to provide cash benefits in the form of vouchers directly payable to professionals, like in the Nordic countries (Colombo et al., 2011).

France. The long-term care system in France is mixed and based on two pillars. The first pillar is healthcare insurance, which covers healthcare costs in residential care, longterm inpatient care units and in-home nurse assistance. The second pillar is the cash benefits 
system (Allocation Personnalisée d'Autonomie (APA) - personal allowance for autonomy), aimed at financing costs of care that are not covered by healthcare insurance (Palier, Naczyk, Morel, 2011: 22). Local communities are authorized to perform needs assessment for custodial care, to define the needed package of services for each beneficiary, to monitor and evaluate services, and to finance a larger portion of the APA allowance (Joël, Dufour-Kippelen, Duchêne, Marmier, 2010: 6).

The French use the term "dependency" rather than long-term care. It directly refers to the age of individual persons, particularly to people over the age of 60 . People under the age of 60 are included in the long-term care system if they enter the category of disabled or handicapped persons (Courbage, Plisson, 2012: 126). Needs assessment for long-term care is carried out on the basis of national standardised dependency scale, the so-called AGGIR (Autonomie Gerontologie Groupes Iso-Ressources) scale. According to this scale, elderly people are classified in six dependency degrees, where AGGIR 1 is a fully dependent person, while AGGIR 6 is an independent person (Courbage, Plisson, 2012: 126, 127). Cash benefits for elderly people (the so-called APA) are allocated to people over 60 who are classified in the first four AGGIR groups, regardless of being accommodated in residential care or at home. This is a universal allowance, but the amount depends on the category of dependency as well as on the total amount of the beneficiary's income. The maximum possible allowance is only granted to beneficiaries with low income; thus, as the income increases, the APA is progressively reduced, even to $80 \%$. A significant characteristic of the APA is that its manner of use is controlled. Beneficiaries must pay professional assistance or hire a family member, but it may not be his/her spouse (Courbage, Plisson, 2012: 127).

As far as financing is considered, the APA is financed by the local government units. But, since 2004, one portion (approximately $30 \%$ of the APA total income) is financed and paid by the National Solidarity Fund for Autonomy (CNSA) ${ }^{3}$ which is financed from contributions for healthcare insurance, taxes and a special $0.1 \%$ "solidarity tax", which is basically a tax on salaries fund. The CNSA also introduced the so-called "solidarity contribution for autonomy" in the form of one "national solidarity day", which is granted by companies working for "free" that day (i.e. all the employees renounce one wage a year). As far as the reform process is concerned, since 2007, there has been an idea to introduce the so-called "fifth social security pillar" - insurance for long-term care, but that intention was abandoned due to the financial crisis (Palier et al, 2011: 23.24).

England. The long-term care system in England is characterised as a "safety net" or a "residual" system supporting only individuals with highly expressed needs for custodial care and assistance, who are unable to pay the expenses. It includes various benefits within the framework of two main pillars: the universal cash benefits system and a complementary system of local level services which are financed only for those whose assets and income are below the specified level (Comas-Herrera, Wittenberg, Pickard, 2010a: 375-376).

As far as the first pillar is concerned, the basic cash benefit is attendance allowance for people over 65 who need custodial care. This allowance is paid for two levels of disability. Such benefits are universal, i.e. paid to all who need care and assistance, regardless of their financial situation. The manner of using this allowances is not controlled

\footnotetext{
${ }^{3}$ The National Solidarity Fund for Autonomy (Fr. CNSA -La Caisse nationale de solidarité pour l'autonomie) was founded in 2004. It is responsible for providing financial support and financing long-term care services to persons who cannot function on their own any longer (Joël et al, 2010:6).
} 
(Comas-Herrera, Pickard, Wittenberg, Malley, King, 2010b: 23). Any person who provides assistance and care (for a minimum of 35 hours a week) to a beneficiary of this allowance is entitled to a carer's allowance, provided that he/she is over the age of 16 and that he/she does not earn more than 95 GBP a week. In addition to such benefit, anyone who provides at least 20-hour care a week is entitled to a "pension credit", i.e. to be assigned pension contributions (Comas-Herrera et al, 2010b: 24). The carer's allowance is not considered earning but a "compensation for lost income". Cash benefits are funded from taxes; thus, they are not tied to the social security system (Hancock, Morciano, Pudney, 2010: 2).

The second pillar of long-term care and assistance in England includes additional services that are within the competence of local community. This type of assistance is available only to individuals in need of assistance whose assets and income are very low. Those people who have been assessed as eligible for social care services are then subject to a means-test to establish whether their services will be funded wholly or partly by the local authority. In England, there is a national charging regime for residential and nursing home care, which takes into account the income and assets of residents (in most cases including any housing wealth). Individuals with assets over the upper limit (currently set at $£ 23,250$ ) are not eligible for local authority support; those with assets below this level are required to contribute most of their income towards the costs of their care (Comas-Herrera et al, 2012: 154, 156). These rules are in force at the national level, so they are the same for all local communities. As far as other services of the local community are concerned, the local community prescribes the types of services, their organisation, criteria for receiving them, and the participation amount. The central authorities provide the instruction on the manner of charging participation, which implies leaving the income of at least $25 \%$ above the social allowance amount to the beneficiary (Comas-Herrera et al, 2010b: 16). The long-term care system in England is very complicated and non-integrated, including huge differences between local communities. Due to very strict assets criterion for exercising the rights, a large number of those who need assistance remain outside the system, thus being required to pay high costs of long-term care. To reform the long-term care system, the UK Government published the Green Paper: Shaping the Future of Care Together in July 2009, suggesting as follows: criteria standardisation at the national level, the increase of the property amount criterion, as well as setting the limit of one's total expenditures for long-term care; once the limit has been reached, the state takes the costs upon itself (Comas-Herrera et al, 2010b: 33).

Austria. Long-term care is a relatively new area of Austrian social policy. The foundations of the Austrian long-term care regime were laid in 1993, by enacting two key legal documents: the Federal Long-term Care Allowance Act (Bundespflegegeldgesetz), and the Agreement between the Federal Republic and the federal provinces (Bundesländer) pursuant to Article 15a of the Constitutional Act. Under this Agreement, the federal provinces are responsible for the development and improvement of decentralised and national provisions of institutional hospital services, short-term in-patient services, semiinpatient (day-care) services, and mobile/out-patient care services (Fink, Valkova, 2018: 6 ). The system comprises two universal schemes of care allowances for persons who need long-term protection and professional protection services within the jurisdiction of (nine) Austrian provinces (Länder) (Trukeschitz, Schneider, 2012: 187-188).

Any individual with physical, mental or psychological disability, including sensory disability, is entitled to the right to long-term care benefit, under two additional conditions: 1) invalidity/disability is expected to last for the next six months at least; and 2) care lasting over 50 hours a month is needed (for applications filed in 1993-2010) or over 60 hours a month 
(for applications filed since January 2011). Long -term care benefit (Pflegegeld) is exclusively conditioned by the beneficiary's need, irrespective of the financial situation of an individual or family, old age or how the invalidity occurred (Trukeschitz, Schneider, 2012: 187-188; European Commission, 2020: 18). The regulations that decision making is based on specify the time needed for performing individual daily activities (dressing, undressing, feeding, etc.). Depending on the degree of invalidity, there are seven levels of cash benefits ranging from category one (for people who require care between 65 and 95 hours per month) to category seven (for people who require care for more than 180 hours, if they cannot purposefully move their arms and legs or there is a similar situation) (European Commission, 2020: 18). In addition, allowance for the costs of 24-hour care was introduced on 1 July 2007. The 24-hour-care support (Förderung der "24-Stunden-Betreuung") is a benefit for dependent persons living in private households (Trukeschitz, Schneider, 2012: 190). The caregiver is either employed by the dependent person or self-employed. He/she resides in the dependent person's household and is directly paid by the dependent person. The financial allowance amount is: 1) EUR 550 or EUR 1,100 per month for employed carers; and 2) EUR 275 or EUR 550 per month for selfemployed care persons (European Commission, 2020: 19).

Another important field in Austria's LTC system is to develop and sustain an adequate supply of professional LTC services. Benefits in kind may encompass mobile and outpatient care, and semi-residential and residential care. Social aspects, such as the income level and rent costs, are considered when benefits in kind are provided by professional providers. Since January 2018, it is no longer allowed to assess (in the context of social assistance) the assets of persons residing in residential care facilities or assets of family, heirs and other donation beneficiaries to cover for the care costs (European Commission, 2020: 18-19)

The Austrian long-term care system in a narrower sense (i.e. without services covered by the healthcare system and private funds) is $100 \%$ financed from taxes. While cash allowance is paid from the general budget of the Federal Republic, in-kind benefits are provided from the budgets of the Federal Republic, provinces and municipalities via a general scheme of fiscal equalization (Finanzlastenausgleich), through which the tax income of the Federal Republic is transferred to federal provinces and municipalities, as well as from the so-called long-term funds (Pflegefonds), first introduced in 2011 (Fink, Valkova, 2018:7, 12, 13).

Germany. In January 1995, after the long-term public debate dating back to the 1970s, Germany established a long-term care system by introducing mandatory insurance for longterm care, as the fifth pillar of social security system (Zuchandke, Reddemann, Krummaker, 2012: 214). Long-term care insurance is directly linked to healthcare insurance; thus, anyone who is insured by the healthcare insurance (either public or private) is automatically "registered" in the long-term care insurance. Given the fact that insurance is mandatory for all employees and that unemployed citizens are insured through their family members, the right to long-term assistance is practically universal. This right may be exercised by all those who paid contributions at least for two years within a ten-year long period preceding the filing of application, and who meet medical requirements for long-term care, regardless of their age and property status (Schmähl, Augurzky, Mennicken, 2014: 21-22). The insurance covers three types of remuneration: care allowance, home care, and residential (institutional) care. Beneficiaries select the type of allowance, and may opt for a combination of cash allowance and service. Cash allowance (care allowance) is considered remuneration for informal care, while services and residential care are considered formal care (Schmähl et al, 2014, 22). 
Long-term care is financed from a special contribution. Since introducing the scheme in 1996, in order to ensure financial sustainability of this branch of social insurance, Germany gradually increased social contribution rates, up to $2.55 \%$ (2.80\% for insurance members who are childless) in 2017. Simultaneously, expenditures for long-term care kept increasing as well, from 14.3 billion Euro in 1997 to 28.3 Euro in 2016 (Zuchandke et al, 2012: 36).

Belgium. Long-term care in Belgium consists of a wide range of benefits in cash and in-kind, which are provided at the federal, regional and municipal levels as part of the federal mandatory healthcare insurance system, and financed from healthcare insurance contributions and general taxes (Willemé, Geerts, Cantillon, Mussche, 2012: 300). Bearing in mind that the entire population is practically covered by the public healthcare insurance, the long-term care system is also almost universal. However, considering that healthcare insurance covers only one part of long-term care (i.e. nurse assistance and a part of personal care for dependant persons), an entire range of services is organised and provided at the regional and local levels. In 2001, the Flemish community founded a specific scheme of insurance for long-term care that is compulsory for all who live in the region of Flanders, and is voluntary for the population of Brussels (Willemé et al, 2012: 300). Generally, the Belgian long-term care system may be described as a mixed system, characterised by extensive formal care financed by the state along with complementary informal care within family (Willemé, 2010: 1). Long-term care is primarily perceived as a healthcare risk, and the institutional arrangement reflects the so-called "medical" model of long-term care (Segaert, 2012: 30). The system is quite complicated due to the complicated organisation of jurisdictions within the state. Healthcare insurance covers most healthcare services while "communities" (i.e. regions) are in charge of services that have the character of social welfare (Segaert, 2012: 30).

The Belgian long-term care system consists of cash benefits and services; notably, services are a more significant component of the system. There are two types of cash benefits. At the federal level, there is "allowance for disabled persons and the elderly" (Tegemoetkoming voor hulp aan bejaarden - THAB), allocated to people above the age of 65 , with minimum seven points on the scale that takes into consideration both the basic daily living activities (BDLA) and instrumental daily living activities (IDLA), restrictions and medical assessment. At the regional level, there is cash allowance received by inhabitants of Flanders who obtain at least 35 points on the BEL-scale, or who prove their need for care with some other alternative means (e.g. proof of residence in a nursing home). There is no age limit, but exercising the right to this benefit is limited to the Flemish citizens and the inhabitants of Brussels as the capital (with some restrictions) (Van Den Bosch, Willemé, Geerts, Breda, Peeters, Van De Sande, Vrijens, Van De Voorde, Stordeur, 2011: 4).

Considering the complexity of organisation of the Belgian long-term care system, including the division of responsibilities between the federal and regional levels, the financial flows are also rather diverse and complex. Generally speaking, a part of long-term care (residential and home care) which is covered by the universal system of healthcare insurance is financed from healthcare insurance contributions paid by employees, employers and pensioners. Beneficiaries participate, but only to certain extent, in the so-called ,maximum billing system" (Willemé et al, 2012, 308-309). Other services and benefits in the long-term care system are financed from general taxes, collected mainly at the federal level. Therefore, a part of these taxes is used for subsidizing the social security budget (including healthcare protection), and the second part is used for subsidies and benefits at the federal and regional 
levels. The Flemish insurance for long-term care is financed from a specific contribution paid by every adult citizen (contributions make up approximately a half of annual budget, and the rest is financed from general taxes) (Willemé, 2010: 5). In budgetary terms, the total public LTC spending is some $1.28 \%$ of GDP for in-kind benefits and some $0.16 \%$ of GDP for cash benefits. The latter reaches $0.31 \%$ of GDP in Flanders with the additional care allowance under the LTC insurance scheme in place since 2001 (Pacolet, De Wispelaere, 2018: 11). ${ }^{4}$

\section{CONCLUSION}

On the basis of the presented comparative law examples, one may conclude that the classification of long-term care systems is quite complicated. There are two basic reasons First, long-term care systems are complex because this area includes healthcare and social welfare centres, combines cash benefits and services, involves various service providers and different methods of their selection. Second, long-term care systems were formed rather late, save for the Scandinavian countries; thus, the question arises as to whether historical differences among the systems in this area are present and evident just as in other segments of the welfare state, such as pension or healthcare systems. When speaking about European countries, we may conclude that the Nordic model is clearly distinctive from other models. All other European countries have very different long-term care systems, based on various combinations of social benefits, ways of financing, organising, the criteria for acquiring the rights, and a different role of the healthcare system, which makes them difficult to classify and define. The closest system to the Nordic model, in terms of responsibility of the state and generosity of the system, is the Dutch system (even though it is organised within the framework of healthcare insurance and largely financed from contributions). On the other hand, although the English model is very frequently distinguished as a special one and classified as a model of social aid or a residual model, it should be noted that it is such only in terms of services, while cash benefits have a universal character. Yet, as the amounts of cash benefits are rather low, we distinguish it as an autonomous model called the English liberal model, where an individual or family should primarily provide assistance and care, while the state is only responsible for the poorest members of society, and only to a symbolic extent for all the others who are in need of support. However, the largest number of countries have a mixed model, involving a combination of services and cash benefits, as well as various forms of organisation, coverage and types of long-term care systems.

Despite numerous differences, we may observe three trends that are common in a majority of states. First, almost all European countries encounter issues related to financing and the right of access to the long-term care system, due to institutional and geographic fragmentation of the system for providing services. Second, there is a clear trend in terms of changing priorities from institutional care to home care. Third, there is a high frequency and expansion of informal care in all the countries, mainly due to the lack of available formal facilities for long-term care, the poor quality and high prices of services, and the

\footnotetext{
${ }^{4}$ The use of a different definition of LTC complicates the comparison between the reports and leads to different levels of spending on LTC. In the AWG Report 2015, the total public spending on LTC in 2013 was estimated at some $2.1 \%$ of GDP, rising to $3.7 \%$ of GDP by 2060. In the most recent national ageing report (Studiecommissie Vergrijzing, 2017: 6), the LTC spending was put at some 1.6\% of GDP in 2016, rising to 2.5\% of GDP by 2060 . For more, see: Pacolet, De Wispelaere, 2018: 11.
} 
general trend of undermining the traditional model of family and inter-generation relationships. In order to compensate for the deficiencies in public services, countries pay cash benefits as financial support for purchasing care from private service providers.

\section{REFERENCES}

Anttonen, A., Sipila, J., (1996). European social care services: Is it possible to identify models?, Journal of European Social Policy, No. 6, 1996.

Bettio, F., Verashchagina, A., (2012). Long-Term Care for the elderly. Provisions and providers in 33 European countries, European Commission, Publications Office of the European Union, Luxembourg.

CoE Revised European Social Charter (CETS No. 163, 1996), Council of Europe, Strasbourg, Retrieved 10 Sept. 2020, https://rm.coe.int/the-european-social-charter-treaty-text/1680799c4b

Colombo, F., Llena-Nozal, A., Mercier, J., Tjadens, F., (2011). Help Wanted? Providing and Paying for Longterm Care, OECD Health Policy Studies, OECD Publishing, Retrieved 15 Nov. 2019 https://read.oecdilibrary.org/social-issues-migration-health/help-wanted_9789264097759-en\#page3

Comas-Herrera, A., Wittenberg, R., Pickard, L., (2012). From Commission to Commission: Financing LongTerm Care in England/ In: Costa-Font, J., Courbage, Ch. (eds.) Financing Long-Term Care in Europe Institutions, Markets and Models, Palgrave Macmillan, Basingstoke, UK.

Comas-Herrera, A., Wittenberg, R., Pickard, L., (2010a). The Long Road to Universalism? Recent Developments in the Financing of Long-term Care in England. Social Policy \& Administration, Vol. 44, No. 4, 2010, Blackwell Publishing, UK.

Comas-Herrera, A., Pickard, L., Wittenberg, R., Malley, J., King, D., (2010b). The English Long-term Care System, ENEPRI Research Report No. 74, European Network of Economic Policy Research Institutes.

Courbage, C., Plisson, M., (2012). Financing Long-Term Care in France/ In: Costa-Font, J., Courbage, Ch. (eds.) Financing Long-Term Care in Europe - Institutions, Markets and Models, Palgrave Macmillan, Basingstoke, UK.

Donders, P., Maarse, H., (2011). Pensions, Health Care, and Long-Term Care-The Netherlands, Anual National Report 2011, European Commission, DG Employment, Social Affairs and Inclusion, Brussels.

European Commission (2020). Your Social Security Rights in Austria, European Commission, DG Employment, Social Affairs and Inclusion, Brussels.

European Parliament (2014). The Open Method of Coordination (OMC), Retrieved 25 October 2020 https://www.europarl.europa.eu/EPRS/EPRS-AaG-542142-Open-Method-of-Coordination-FINAL.pdf.

Fink, M., Valkova, K., (2018). ESPN Thematic Report on Challenges in long-term care - Austria, European Social Policy Network (ESPN), European Commission, DG Employment, Social Affairs and Inclusion, Brussels.

Hancock, R., Morciano, M., Pudney, S., (2010). Attendance Allowance and Disability Living Allowance claimants in the older population: Is there a difference in their economic circumstances?, ISER Working Paper Series, No. 2010-27, Institute for Social and Economic Research, University of Essex, Colchester.

Ilinca, S., Leichsenring, K., Rodrigues, R., (2015). From care in homes to care at home: European experiences with (de)institutionalisation in long-term care, Policy Brief, European Center for Social Welfare Policy and Research, Vienna.

Jašarević S., (2013). Socijalno pravo (Social Law), Centar za izdavačku delatnost Pravnog fakulteta Univerziteta u Novom Sadu, Novi Sad.

Joël, M. E., Dufour-Kippelen, S., Duchêne, C., Marmier M., (2010). The Long-term Care System for the Elderly in France, ENEPRI Research Report No. 77, European Network of Economic Policy Research Institutes.

Lipszyc, B., Sail, E., Xavie, A., (2012). Long-term care: Need, use and expenditure in the EU-27, Economic Papers 469, European Commission, DG for Economic and Financial Affairs, Brussels.

Mot, E., Aouragh, A., De Groot, M., Mannaerts, H., (2010). The Dutch System of Long-term Care, ENEPRI Research Report No. 90, European Network of Economic Policy Research Institutes.

Muir, T., (2017). Measuring social protection for long-term care, OECD Health Working Papers, No. 93, OECD Publishing, Paris.

OECD (2005), Long-Term Care for Older People, OECD Health Project, the Organisation for Economic Cooperation and Development, Brussels, accessed on 23 November 2019 https://read.oecd-ilibrary.org/socialissues-migration-health/long-term-care-for-older-people_9789264015852-en\#page11.

Palier, B., Naczyk, M., Morel, N. (2010). Pensions, Health and Long-term Care - France, Annual National Report 2010, European Commission, DG Employment, Social Affairs and Inclusion, Brussels.

Republički zavod za socijalnu zaštitu (2008): Kozarčanin, L., (koordinator), O evropskom konceptu dugotrajne zaštite i praktičnim iskustvima u pilot projektu akreditacije programa usluga dugotrajne zaštite u Srbiji (On 
the European Long-term Protection Concept and Practical Experiences in the Long-term Protection Services Programme Accreditation - pilot project), Socijalna misao, No. 60/2008, Beograd.

Satarić, N., Milićević Kalašić, A., (2014), Život bez sećanja - Istraživanje o potrebama za Dnevnim centrom za demente u Beogradu, (Life without Memory- Reserach on the need for a Day-care center for dementiaaffected users in Belgrade), deo projekta "Ne zaboravimo mi one koji zaboravljaju", podržan od USAID-a, Beograd.

Schmähl, W., Augurzky B., Mennicken R. (2014). Pensions, health and long-term care - Germany, Country Document Update 2014, European Commission, DG Employment, Social Affairs and Inclusion, Brussels.

Schulz, E., (2010). The Long-Term Care System in Denmark, DIW Berlin Discussion Paper No. 1038, German Institute for Economic Research, Berlin.

Schut, F., Van den Berg, B., (2012). Long-Term Care Insurance in the Netherlands, In: Costa-Font, J., Courbage, Ch. (eds.) Financing Long-Term Care in Europe - Institutions, Markets and Models, Palgrave Macmillan, Basingstoke, UK.

Shut, F., Sorbe, S., Høj, J., (2013). Health Care Reform and Long-Term Care in The Netherlands, OECD Economics Department Working Papers No. 1010, Brussels.

Segaert, S., (2012). Pensions, Health Care and Long-term Care: Belgium, Annual National Report 2012, European Commission, DG Employment, Social Affairs and Inclusion, Brussels.

Spasova, S., Baeten, R., Coster, S., Ghailani, D., Peña-Casas, R., Vanhercke, B., (2018). Challenges in long-term care in Europe - A study of national policies, European Commission, European Social Policy Network (ESPN), Brussels.

Trukeschitz, B., Schneider, U., (2012). Long-Term Care Financing in Austria/ In Costa-Font, J. Courbage, C. (eds.), Financing Long-Term Care in Europe - Institutions, Markets and Models, Palgrave Macmillan, Basingstoke, UK.

Willemé, P., (2010). The Belgian Long-Term Care System, ENEPRI Research Report No. 70, European Network of Economic Policy Research Institutes.

Willemé, P., Geerts J., Cantillon B., Mussche N., (2012). Long-Term Care Financing in Belgium/ In Costa-Font, J. Courbage, C. (eds.), Financing Long-Term Care in Europe - Institutions, Markets and Models, Palgrave Macmillan, Basingstoke, UK.

Van Den Bosch, K., Willemé, P., Geerts, J., Breda, J., Peeters, S., Van De Sande, S., Vrijens, F., Van De Voorde, C., Stordeur, S., (2011). Residential Care for Older Persons in Belgium: Projections 2011 - 2025 Synthesis, KCE Reports 167c, Health Services Research, Belgian Health Care Knowlegde Centre (KCE), Brussels.

Zuchandke, A., Reddemann, S., Krummaker, S., (2012). Financing Long-Term Care in Germany/ In Costa-Font, J. Courbage, C. (eds.), Financing Long-Term Care in Europe - Institutions, Markets and Models, Palgrave Macmillan, Basingstoke, UK.

\section{UPOREDNOPRAVNI PREGLED SISTEMA DUGOTRAJNE NEGE U NEKIM EVROPSKIM DRŽAVAMA}

Organizacija i finansiranje sistema dugotrajne nege je jedno od najčěsce raspravljanih pitanja socijalne politike razvijenih evropskih zemalja još od sredine devedesetih godina XX veka. Ključno pitanje u raspravi o sistemu dugotrajne nege jeste u kojoj meri stanovništvo treba da finansira svoje sopstvene potrebe za tuđom negom i pomoći, a u kojoj meri to treba da čini država. Pored toga, posebno važno je $i$ pitanje da li sredstva za dugotrajnu negu treba da budu od koristi samo onima koji ne mogu platiti iz sopstvenih sredstava (rezidualni model) ili bi usluge dugotrajne nege trebalo da budu univerzalno pravo. Intezitetu ove rasprave doprinelo je postojanje velikih nacionalnih razlika, kako u pogledu načina na koji se sistem organizuje, tako i prema tipu/vrsti davanja i načinu kako se generišu resursi. Imajući u vidu navedeno, autor u radu analizira sisteme dugotrajne nege lica zavisnih od tuđe nege i pomoći u nekoliko najrazvijenih evropskih zemalja, sa osnovnim ciljem da sagleda moguće načine njihove organizacije $i$ finansiranja, kao i da istakne njihove glavne prednosti i mane, što, eventualno, može poslužiti kao putokaz za unapređenje domaćeg sistema.

Ključne reči: dugotrajna nega, sitem, organizacija, finansiranje 